\title{
Covid-19: Japan ends state of emergency but warns of "new normal"
}

\author{
Mun-Keat Looi
}

The BMJ

Japan has ended its state of emergency a week early after its new infections fell below 50 a day.

"What was once nearly 10000 hospitalised cases, that has now fallen below 2000," the prime minister, Shinzo Abe, declared in a news conference on 25 May. Restrictions had been due to stay in place until 31 May. He acknowledged, however, that the number of infections could not be brought to zero and that Japan would have to adjust to a "new normal."

On 26 May Tokyo began a three phase process of reopening businesses with distancing restrictions. Restaurants and department stores are among those that have already reopened using restricted hours and customer entry, with schools and libraries to follow, while gyms and karaoke boxes will open by 1 June and live music venues and bars by 19 June. Domestic air travel is also set to resume, but international borders remain restricted, as foreign visitors will be asked to quarantine for 14 days after arriving in the country.

Abe had already ended the state of emergency for 39 of Japan's 47 prefectures on 13 May after significant drops in hospital admissions and new infected cases, but several regions, including Tokyo and Osaka, remained under watch. More than 17000 people have tested positive for the coronavirus, with over 850 deaths.

\section{Cluster tracing}

Japan had seen an explosion of cases in April, leading to the state of emergency requiring all citizens to maintain social distancing and stay indoors. ${ }^{1}$ That declaration coincided with the 10 day "Golden Week" period of consecutive public holidays, which normally sees huge numbers of citizens travelling home or abroad. But this year people refrained from travelling outside their prefecture and remained at home.

Public adherence to the rules, along with cluster tracing and a ban on mass gatherings, seems to have achieved success in bringing the outbreak under control, alongside widespread mask use and hygiene being a normal part of Japanese etiquette.

However, experts warned that a second wave could still occur and that testing and tracing remained paramount in preventing another explosion in cases. Japan has raised the number of tests done daily to over 20000 , relaxed testing criteria to allow more people to be tested, and added faster, though less accurate, antigen tests to supplement polymerase chain reaction (PCR) testing capacity.
The health ministry also intends to launch large scale antigen testing to discover the extent of infections, aiming to test 10 000 people in Tokyo, Osaka, and Miyagi prefectures by early June. This follows claims that the low amount of testing in the early phases of the outbreak has left the true number of infections unknown.

\section{Drug approval}

The ministry has also pledged to fast track approval for the drug remdesivir in covid-19 treatment. But Kato Katsunobu, health minister, said that approval of the Japan made anti-flu drug Avigan would be postponed to June, citing ongoing clinical trials. $^{2}$

On 26 May the Abe government approved US\$1.7bn ( $£ 1.38 \mathrm{bn}$; $€ 1.55 \mathrm{bn}$ ) to obtain medical supplies such as personal protective equipment, ventilators, and extracorporeal membrane oxygenation (ECMO) machines and to shoulder around $\$ 148 \mathrm{~m}$ in patient fees through the public health insurance system, acknowledging the high costs incurred by hospitals accepting covid-19 patients.

The health ministry is also considering paying as much as $\$ 1900$ for each frontline medical worker at hospitals treating covid-19 patients nationwide. The Kyodo news agency reported that the proposal included providing $¥ 200000$ (£1504; €1692; \$1859) for each frontline worker at hospitals admitting coronavirus patients, as well as $¥ 100000$ for each staff member at medical institutions that have secured beds and prepared to admit coronavirus patients.

Staff at nursing homes are also likely to be eligible for the allowance. Tottori Prefecture had already announced that it would pay $¥ 4000$ a day to all medical workers handling coronavirus cases. $^{3}$

Looi MK. Covid-19: Japan declares state of emergency as Tokyo cases soar. BMJ 2020;369:m1447. 10.1136/bmj.m1447 32273382

2 Avigan won't be approved as COVID-19 drug in May. NHK World News 2020 May 26. https://www3.nhk.or.jp/nhkworld/en/news/20200526_20/.

3 Japan considers giving $¥ 200000$ per staff at hospitals treating COVID-19 patients. Japan Times 2020 May 24. https://www.japantimes.co.jp/news/2020/05/24/national/japan-mullsgiving-\%C2\%A5200000-per-staff-hospitals-treating-covid-19-patients.

This article is made freely available for use in accordance with BMJ's website terms and conditions for the duration of the covid-19 pandemic or until otherwise determined by BMJ. You may use, download and print the article for any lawful, non-commercial purpose (including text and data mining) provided that all copyright notices and trade marks are retained.

https://bmj.com/coronavirus/usage 
